\title{
Effect of Funneliformis mosseae on growth, mineral nutrition, biochemical indexes and chlorophyll content of Ziziphus spina-christi seedlings at different salinities
}

\author{
Javad Mirzaei, Younes Mirzaei, \\ Hamid Reza Naji
}

\section{Introduction}

Soil salinity is a chronic problem increasing worldwide, especially in arid and semiarid areas (Al-Karaki 2006). At least 6\% of the global landmass is affected by salinity (FAO 2007). Three types of physiological stress affect plant growth in saline soils: (i) toxic effects of specific ions, such as sodium and chloride, on plant cells (Juniper \& Abbott 1993); (ii) physiological drought in soil with low osmotic potential, due to the plant efforts to maintain a lower internal osmotic potential, thus preventing water

\begin{abstract}
Vast area of the land around the world is saline. Knowledge of plant behavior and their interaction with mychorrizal fungi in saline areas may help seedling establishment in such environments. This study aimed to determine the effects of the inoculation of the fungus Funneliformis mosseae (FM) on Ziziphus spina-christi (Rhamnaceae) plants grown under salt stress. Mycorrhizal and non-mycorrhizal seedlings were exposed to different levels of $\mathrm{NaCl}$ in the soil $(0,50,100$, and $150 \mathrm{mM})$. The following parameters were measured in both inoculated and non-inoculated plants: root colonization rate, seedling height, root diameter, root and shoot dry weights, chlorophyll $a$ and $b$, total nitrogen $(\mathrm{N})$, phosphorus $(\mathrm{P})$, potassium $(\mathrm{K})$ and sodium $\left(\mathrm{Na}^{+}\right)$content, proline accumulation in roots and leaves, superoxide dismutase (SOD), peroxidase (POD) and catalase (CAT) activities. The results showed that soil salinity hampered the root colonization by the fungus, and decreased basal diameter, seedling height, root and shoot dry weights, as well as some nutrients and chlorophyll a concentration, while increased leaves and roots $\mathrm{Na}^{+}$, SOD and POD activity, proline accumulation, as well as CAT activity in the roots. Contrastingly, no significant effect of soil salinity were detected on K and CAT of leaves, root N, and chlorophyll $b$. Inoculated plants had higher basal diameter, leaves and roots $\mathrm{P}$, root and shoot dry weights, chlorophyll $a$ and lower SOD content, proline accumulation in leaves and $\mathrm{Na}^{+}$, as compared with non-inoculated plants. Seedling height, root N, CAT and POD content, and chlorophyll $b$ were not affected by inoculation with FM. These results demonstrated that FM inoculation is a promising method for improving the growth of $Z$. spina-christi seedlings under salt stress.
\end{abstract}

Keywords: Salinity, Peroxidase, Chlorophyll, Arbuscular Mycorrhiza, Ziziphus spina-christi

egression from roots into the soil; and (iii) imbalances of the nutrient content caused by the decreased nutrient uptake and/or transport to the leaves (Adiku et al. 2001).

To mitigate the effects of soil salt on plant growth, many strategies have been developed, including the use of seedlings with roots colonized by arbuscular mycorrhizal fungi (AMF - Wu et al. 2010, Yang et al. 2014). AMF have symbiotic relationship with the roots of over $80 \%$ of the terrestrial plant species, including halophytes, hydrophytes and xerophytes (Hejiden et al.

Dept. of Forest Science, Ilam University, Ilam (Iran)

@ Javad Mirzaei (j.mirzaei@mail.ilam.ac.ir)

Received: Mar 11, 2015 - Accepted: Jul 21, 2015

Citation: Mirzaei J, Mirzaei Y, Naji HR (2015). Effect of Funneliformis mosseae on growth, mineral nutrition, biochemical indexes and chlorophyll content of Ziziphus spina-christi seedlings at different salinities. iForest 9: 503-508. - doi: 10.3832/ifor1643-008 [online 201512-08]

Communicated by: Silvano Fares

1998). Indeed, It has been demonstrated that AMF colonization increases the tolerance of some plants to salt (Tian et al. 2004). AMF are mutually symbiotic and provide a direct physical link between the soil and plant roots (Gaur \& Adholeya 2004).

AMF promotes salinity tolerance by increasing nutrient uptake (Evelin et al. 2012, Beltrano et al. 2013), improving rhizospheric and soil conditions (Asghari et al. 2005), increasing photosynthesis and water use efficiency (Hajiboland et al. 2010), the accumulation of compatible solutes (Evelin et al. 2012) and enzymatic antioxidants such as superoxide dismutase (SOD), peroxidase (POD) and catalase (CAT) as a defense system to protect the plant cell from oxidative stress (Wu et al. 2010, Lu et al. 2014).

Funneliformis mosseae (FM) is an arbuscular mycorrhiza used to alleviate salt stress in Arachis hypogaea (Al-Khaliel 2010), Capsicum annuum (Abdel Latef 2013), Poncirus trifoliate (Wu et al. 2010) and Olea europaea (Porras-Soriano et al. 2009) seedlings. Symbiotic relationships between Funneliformis mosseae and several species of the genus Ziziphus (Rhamnaceae) have been 
Tab. 1 - Physico-chemical characteristics of soil used in this experiment. (EC): electrical conductivity; (OC): organic carbon; (Ca): Calcium; (N): Nitrogen; (P): Phosphor; (K): Potassium; (Mg): Magnesium; $\left(\mathrm{Na}^{+}\right)$: Sodium.

\begin{tabular}{lc}
\hline Parameter & Value \\
\hline $\mathrm{pH}$ & 7.32 \\
$\mathrm{EC}\left(\mathrm{mmho} \mathrm{cm} \mathrm{cm}^{-1}\right)$ & 0.52 \\
$\mathrm{OC}(\%)$ & 1.5 \\
$\mathrm{Ca}(\%)$ & 5.4 \\
$\mathrm{~N}\left(\mathrm{~g} \mathrm{~kg}^{-1}\right)$ & 0.12 \\
$\mathrm{P}(\mathrm{ppm})$ & 19.6 \\
$\mathrm{~K}(\mathrm{ppm})$ & 601 \\
$\mathrm{Mg}^{(\mathrm{ppm})}$ & 0.6 \\
$\mathrm{Na}^{+}\left(\mathrm{g} \mathrm{kg}^{-1}\right)$ & 1.1 \\
Texture & Loamy-Clay \\
\hline
\end{tabular}

formerly reported (Bisen et al. 1995, Prasad et al. 2011).

The aim of this study was to determine the effects of the mychorrizal fungus Funneliformis mosseae (FM) on the growth of Ziziphus spina-christi seedlings exposed to different soil salinity levels. Our starting hypothesis was that the FM inoculum could alleviate the effect of salinity stress in Z. spina-christi seedlings.

\section{Material and methods}

\section{Plant material and $A M$ inoculum}

Experimental plants (Ziziphus spinachristi) were initially produced from seeds. The mycorrhizal inoculum of Funneliformis mosseae (FM, formerly known as Glomus mosseae) were originally purchased from the Tarbiat Modares University, Tehran, (Iran), and then propagated by trap culture technique in the rhizosphere of maize (Zea mays) roots for 5 months.

\section{Growth conditions and methodology}

The experiment was carried out in a forest nursery located in Mehran (western Iran) between February and August 2013 (6 months). The mean temperature was 19.5 ${ }^{\circ} \mathrm{C}$ and precipitation was $245.5 \mathrm{~mm}$. Seeds of $Z$. spina-christi were scarified to overcome hard seed coat dormancy by removing a small portion of the coat at the cotyledon end with nail clippers. The seeds were germinated in a mixture of clay, silt

and perlite (2:1:1 v/v - Tab. 1). About 10\% $(\mathrm{w} / \mathrm{w})$ inoculum of $\mathrm{FM}$ was placed in the pots at sowing time. The FM inoculum consisted of soil, spores (50 spores $\mathrm{g}^{-1}$ inoculum), hyphae and root fragments. To ensure uniform soil conditions, sterilized inoculum was also added to the control pots (non-mycorrhiza).

Seedling were grown for 5 weeks before being treated with one of four levels of $\mathrm{NaCl}(0,50,100$ and $200 \mathrm{mM})$. The salt was added to the soil with the irrigation water. The soil was salinized step-wise to avoid subjecting the plants to osmotic shock. The $\mathrm{NaCl}$ concentration was gradually increased by $25 \mathrm{mM}$ on alternative day to reach the required salinity. The pots were daily weighed to measure water loss, which was replaced with deionized water to avoid percolation and maintain the soil water potential at field capacity.

\section{Determination of growth parameters} and colonization

The plants were harvested 6 months after planting and the height and basal diameter of the seedlings were measured. The shoots (leaves and stems) and roots were then oven-dried at $70^{\circ} \mathrm{C}$ for $72 \mathrm{~h}$ and their dry weight (DW) was calculated at $0.01 \mathrm{~g}$ precision (Meloni et al. 2004).

Determination of the percentage of roots colonization was carried out according to the method suggested by Phillips \& Hayman (1970). Ten thin fragments of roots each with length of about $1 \mathrm{~cm}$ were collected from several seedlings for each treatment. The percentage of colonization (AM\%) was determined by the following formula (eqn. 1):

$$
A M \%=\frac{R L_{i}}{R L_{o}} \cdot 100
$$

where $R L_{\mathrm{i}}$ and $R L_{\mathrm{o}}$ were the infected and the overall root length, respectively.

\section{Leaf and root nutrient analysis}

Physiologically mature leaves and roots were randomly collected from selected seedlings in each treatment. Leaves were pooled, ground finely and sieved through a $40 \mu \mathrm{m}$ mesh screen. Total nitrogen $(\mathrm{N})$ was measured using the semi-micro Kjeldahl method (Nelson \& Sommers 1982). Potassium (K), phosphor $(\mathrm{P})$ and sodium ( $\mathrm{Na})$

$$
\begin{aligned}
& \text { Fig. } 1 \text { - Effect of } \\
& \text { salt stress on root } \\
& \text { colonization of } Z \text {. } \\
& \text { spina-christi seed- } \\
& \text { lings. Different let- } \\
& \text { ters indicate signi- } \\
& \text { ficant differences } \\
& \text { between treat- } \\
& \text { ments }(p<0.05) \text {. }
\end{aligned}
$$

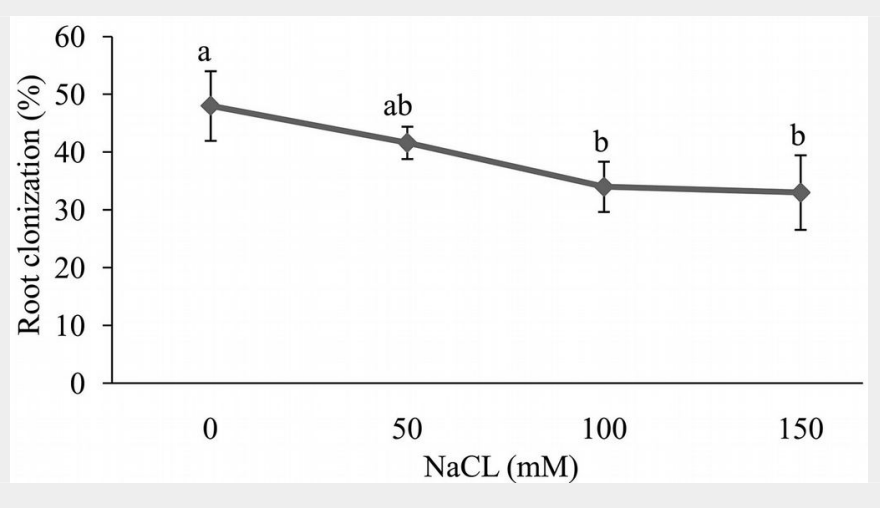

contents were determined by atomic absorption spectrophotometry (UV/VIS 9000).

\section{Enzyme assays}

Fresh matured leaves were detached from seedlings for enzyme measurement (Jin et al. 2012). Some $0.5 \mathrm{~g}$ of frozen leaves were ground in liquid nitrogen until a fine powder was obtained. The same method was applied for fine root samples. The powder was extracted using an ice-cold 50 $\mathrm{nM}$ phosphate buffer at $\mathrm{pH}$ 7.0. The extracts were centrifuged (Rotina 380; Hettich) at $4^{\circ} \mathrm{C}$ for $20 \mathrm{~min}$ at $13000 \mathrm{rpm}$, and the supernatant was collected for antioxidant enzyme analyses (Mirzaei \& Yousefzadeh 2013). The superoxide dismutase (SOD) activity was determined using potassium phosphate $(\mathrm{pH}=7.5), \mathrm{Na}_{2} \mathrm{CO}_{3}$ $(\mathrm{pH}=10.2)$ according to the method described by Giannopolitis \& Ries (1977). The peroxidase (POD) activity was determined using the Guaiacol oxidation method (Kar \& Mishra 1976). The catalase (CAT) was measured using potassium phosphate $(\mathrm{pH}$ $=7.0$ ) and $\mathrm{H}_{2} \mathrm{O}_{2}$ (Cakmak \& Horst 1991). Proline accumulation was determined using ninhydrin and sulfosalicylic acid (Bates et al. 1973).

\section{Leaf chlorophyll content}

Semi-mature leaflets $(n=32)$ were collected from seedlings to measure their chlorophyll content ( $a, b$ and total), which was extracted using $80 \%$ acetone (Harborne 1998). The supernatant was quantified with a spectrophotometer at 645 and 663 $\mathrm{nm}$ and compared to a blank $80 \%$ acetone standard. Chlorophyll content was expressed as $\mathrm{mg} \mathrm{g}^{-1}$ fresh weight (Al-Khaliel 2010).

\section{Experimental design and statistical}

\section{analysis}

The experiment was performed using a random design with 4 replications on 4 seedlings per treatment. All parameters were analyzed using the analysis of variance (ANOVA). Treatment means were compared using the post-hoc Duncan' test at the significance level of 0.05 .

\section{Results}

\section{Root colonization}

Overall, salt stress had a significant effect on colonization of $Z$. spina-christi seedling roots by Funneliformis mosseae. By increasing the soil salinity, FM colonization was decreased by $48 \%$ to $33 \%$. However, no significant difference was observed between salt concentration in the soil of 100 and 150 $\mathrm{mM}$. The highest level of FM colonization was in the control, while the lowest was in 100 and $150 \mathrm{mM}$ treatments (Fig. 1).

\section{Growth indexes}

Tab. 2 shows the effects of FM on $Z$. spina-christi tolerance to salt stress as inferred from the change in growth indexes. Under salt stress seedlings' basal diame- 
ters were significantly decreased, with the lowest values shown by seedlings grown at $150 \mathrm{mM}$ soil salinity. At all levels of soil salinity, the basal diameter of FM-inoculated plants was significantly higher than that of non-inoculated seedlings. Likewise, salinity significantly decreased seedlings' height. Contrastingly, no significant difference was detected between the height of inoculated and non-inoculated seedlings at low levels of salinity (o and $50 \mathrm{mM}$ ). The root dry weight (RDW), a proxy of total dry matter, was also decreased under salt stress, while FM-inoculation increased RDW at all levels of salt stress (Tab. 2).

Shoot dry weight (SDW) under salinity was highly decreased, as the highest and lowest levels were in control and $150 \mathrm{mM}$ of salinity, respectively. Moreover, it was observed that SDW of FM-inoculated seedlings was increased as compared with nonmycorrhizal plans. Height values showed that salt-stressed mycorrhizal Z. spinachristi had significantly greater SDW than salt-stressed non-mycorrhizal plants. Furthermore, there was an increase in SDW of mycorrhizal plants at all levels of salinity ( 0 , 50, 100 and $150 \mathrm{mM}$ ); however, at high levels of salt stress ( 50 and $100 \mathrm{mM}$ ) a severe decrease in SDW in both mycorrhizal and non-mycorrhizal plants was evident. This may be related to the adverse effects of salinity on photosynthesis (Fig. 2).
Tab. 2 - Effects of salt stress on diameter, height and RDW of mycorrhizal and nonmycorrhizal seedlings of $Z$. spina-christi. Means \pm standard errors are reported. The signs $(+,-)$ indicate the presence/absence of Funneliformis mosseae. Means in the same column followed by the same letter are not significantly different $(p>0.05)$ after the Duncan's post-hoc test. (ns): not significant.

\begin{tabular}{|c|c|c|c|c|}
\hline $\begin{array}{l}\text { Treatment } \\
(\mathrm{nM} \mathrm{NaCl})\end{array}$ & $\begin{array}{l}A M \\
\text { inoculation }\end{array}$ & $\begin{array}{l}\text { Basal diameter } \\
(\mathrm{mm})\end{array}$ & $\begin{array}{l}\text { Height } \\
\text { (cm) }\end{array}$ & $\begin{array}{l}\text { RDW } \\
\text { (g) }\end{array}$ \\
\hline 0 & $\begin{array}{l}+F M \\
-F M\end{array}$ & $\begin{array}{l}3.93 \pm 0.25^{a} \\
1.33 \pm 0.25^{d}\end{array}$ & $\begin{array}{l}28.8 \pm 4.5^{a} \\
28.8 \pm 4.8^{a}\end{array}$ & $\begin{array}{l}4.12 \pm 0.38^{a} \\
1.52 \pm 0.38^{c d}\end{array}$ \\
\hline 50 & $\begin{array}{l}+F M \\
-F M\end{array}$ & $\begin{array}{l}3.17 \pm 0.222^{\mathrm{ab}} \\
0.63 \pm 0.17^{\mathrm{de}}\end{array}$ & $\begin{array}{l}14.4 \pm 1.9^{b} \\
15.4 \pm 1.9^{b}\end{array}$ & $\begin{array}{l}2.76 \pm 0.27^{b} \\
0.62 \pm 0.24^{\text {ef }}\end{array}$ \\
\hline 100 & $\begin{array}{l}+F M \\
-F M\end{array}$ & $\begin{array}{l}3.05 \pm 0.40^{b} \\
0.61 \pm 0.31 \text { de }\end{array}$ & $\begin{array}{r}12.0 \pm 1.4^{b} \\
7.8 \pm 2.9^{b}\end{array}$ & $\begin{array}{l}2.10 \pm 0.20^{b c} \\
0.30 \pm 0.15^{f}\end{array}$ \\
\hline 150 & $\begin{array}{l}+F M \\
-F M\end{array}$ & $\begin{array}{l}2.20 \pm 0.22^{c} \\
0.20 \pm 0.17^{\mathrm{e}}\end{array}$ & $\begin{array}{l}8.8 \pm 0.7^{b} \\
7.4 \pm 2.0^{b}\end{array}$ & $\begin{array}{l}1.10 \pm 0.22^{d e} \\
0.04 \pm 0.02^{f}\end{array}$ \\
\hline Main effects & $\begin{array}{l}\mathrm{NaCl} \\
\mathrm{AM}\end{array}$ & $\begin{array}{l}\mathrm{p}<0.001 \\
\mathrm{p}<0.001\end{array}$ & $\begin{array}{l}\mathrm{p}<0.001 \\
\mathrm{~ns}\end{array}$ & $\begin{array}{l}\mathrm{p}<0.001 \\
\mathrm{p}<0.001\end{array}$ \\
\hline Interaction effects & $\mathrm{NaCl} \times \mathrm{AM}$ & ns & ns & ns \\
\hline
\end{tabular}

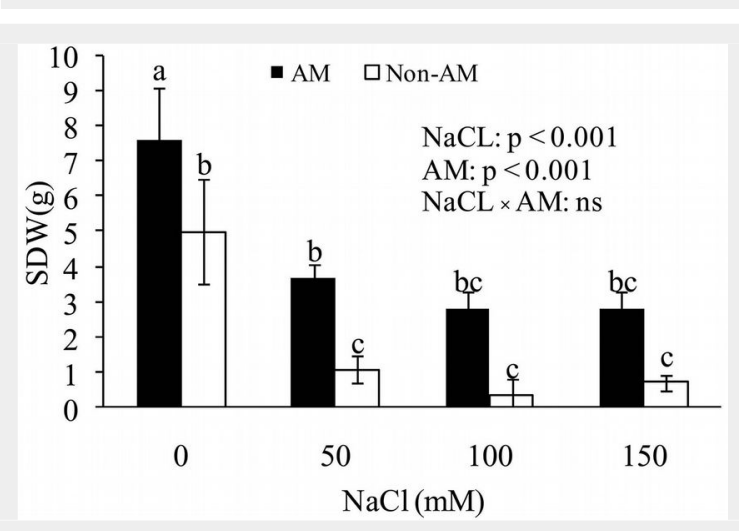

Fig. 2 - Effect of salt stress on shoot dry weight (SDW) of mycorrhizal and non-mycorrhizal seedlings of Z. spinachristi. Different letters indicate significant differences between treatments $(\mathrm{p}<$ 0.05). (ns): not significant.

Tab. 3 - Effect of salt stress on N, P and K absorption of mycorrhizal and non-mycorrhizal seedlings of Z. spina-christi. Means \pm standard errors are reported. The signs (+, -) indicate the presence/absence of Funneliformis mosseae. Means in the same column followed by the same letter are not significantly different ( $p>0.05$ ) after the Duncan's post-hoc test. (ns): not significant.

\begin{tabular}{|c|c|c|c|c|c|c|c|}
\hline \multirow{2}{*}{$\begin{array}{l}\text { Treatment } \\
(\mathrm{mM} \mathrm{NaCl})\end{array}$} & \multirow{2}{*}{$\begin{array}{l}\text { AM } \\
\text { inoculation }\end{array}$} & \multicolumn{2}{|l|}{$\mathrm{N}\left(\mathrm{gr} \mathrm{kg}^{-1}\right)$} & \multicolumn{2}{|l|}{ P (ppm) } & \multicolumn{2}{|l|}{ K (ppm) } \\
\hline & & Leaf & Root & Leaf & Root & Leaf & Root \\
\hline \multirow[t]{2}{*}{0} & $+F M$ & $3.92 \pm 0.29^{a}$ & $2.82 \pm 0.53^{\mathrm{a}}$ & $3.85 \pm 0.47^{a}$ & $4.11 \pm 0.24^{a}$ & $3.09 \pm 1.02^{a}$ & $2.98 \pm 0.83^{a}$ \\
\hline & - FM & $2.72 \pm 0.27^{b}$ & $2.02 \pm 0.36^{a}$ & $3.05 \pm 0.47 \mathrm{ab}$ & $3.31 \pm 0.24 \mathrm{ab}$ & $2.31 \pm 1.01^{\mathrm{a}}$ & $2.18 \pm 0.83$ ab \\
\hline \multirow[t]{2}{*}{50} & $+F M$ & $2.94 \pm 0.28^{b}$ & $1.48 \pm 0.10^{\mathrm{a}}$ & $3.52 \pm 0.30^{\mathrm{a}}$ & $3.05 \pm 0.12 \mathrm{abc}$ & $2.76 \pm 0.68^{a}$ & $2.59 \pm 0.40^{\mathrm{a}}$ \\
\hline & $-F M$ & $2.74 \pm 0.28^{b}$ & $1.28 \pm 0.10^{\mathrm{a}}$ & $2.72 \pm 0.30^{\mathrm{b}}$ & $2.25 \pm 0.12 \mathrm{bcd}$ & $1.96 \pm 0.68^{a}$ & $1.80 \pm 0.40$ ab \\
\hline \multirow[t]{2}{*}{100} & $+F M$ & $2.42 \pm 0.17^{b}$ & $1.50 \pm 0.23^{a}$ & $2.12 \pm 0.38^{b}$ & $1.93 \pm 0.27^{\mathrm{cd}}$ & $2.50 \pm 1.42^{a}$ & $1.60 \pm 0.33^{\mathrm{ab}}$ \\
\hline & - FM & $2.32 \pm 0.20^{\mathrm{bc}}$ & $1.62 \pm 0.24^{\mathrm{a}}$ & $1.32 \pm 0.38^{\mathrm{bc}}$ & $1.13 \pm 0.27^{d}$ & $1.74 \pm 0.41^{\mathrm{a}}$ & $0.80 \pm 0.32^{b}$ \\
\hline \multirow[t]{2}{*}{150} & $+F M$ & $2.20 \pm 0.27^{b c}$ & $1.78 \pm 0.39^{\mathrm{a}}$ & $0.98 \pm 0.17^{c}$ & $1.85 \pm 0.71^{d}$ & $1.19 \pm 0.28^{a}$ & $1.44 \pm 0.09$ ab \\
\hline & $-F M$ & $1.60 \pm 0.23^{c}$ & $1.58 \pm 0.39^{\mathrm{a}}$ & $0.28 \pm 0.12^{c}$ & $1.26 \pm 0.60^{d}$ & $0.45 \pm 0.25^{\mathrm{a}}$ & $0.64 \pm 0.09^{b}$ \\
\hline \multirow[t]{2}{*}{ Main effects } & $\mathrm{NaCl}$ & $p<0.001$ & ns & $p<0.001$ & $p<0.001$ & ns & $p<0.001$ \\
\hline & $\mathrm{AM}$ & $p<0.001$ & ns & $\mathrm{p}<0.001$ & $p<0.001$ & ns & $p<0.05$ \\
\hline Interaction effects & $\mathrm{NaCl} \times \mathrm{AM}$ & ns & ns & ns & ns & ns & ns \\
\hline
\end{tabular}

Tab. 4 - Effect of salt stress on $\mathrm{Na}^{+}$absorption and chlorophyll ( $a$ and $b$ ) on mycorrhizal and non-mycorrhizal seedlings of Z. spinachristi. Means \pm standard errors are reported. The signs $(+,-)$ indicate the presence/absence of Funneliformis mosseae. Means in the same column followed by the same letter are not significantly different ( $p>0.05$ ) after the Duncan's post-hoc test. (ns): not significant.

\begin{tabular}{|c|c|c|c|c|c|}
\hline \multirow{2}{*}{$\begin{array}{l}\text { Treatment } \\
(\mathrm{mM} \mathrm{NaCl})\end{array}$} & \multirow{2}{*}{$\begin{array}{l}\text { AM } \\
\text { inoculation }\end{array}$} & \multicolumn{2}{|l|}{$\mathrm{Na}^{+}\left(\mathrm{g} \mathrm{kg}^{-1}\right)$} & \multicolumn{2}{|c|}{ Chlorophyll (Mg g ${ }^{-1}$ fresh weight) } \\
\hline & & Leaf & Root & $a$ & $b$ \\
\hline \multirow[t]{2}{*}{0} & $+F M$ & $22.90 \pm 4.19^{c}$ & $16.56 \pm 3.08^{c}$ & $3.02 \pm 0.39^{a}$ & $0.43 \pm 0.10^{\mathrm{a}}$ \\
\hline & $-F M$ & $22.90 \pm 4.19^{c}$ & $22.80 \pm 3.08^{c}$ & $1.62 \pm 0.19 \mathrm{bc}$ & $0.15 \pm 0.08^{\mathrm{a}}$ \\
\hline \multirow[t]{2}{*}{50} & $+F M$ & $37.26 \pm 2.58 b c$ & $34.40 \pm 2.40^{b}$ & $1.68 \pm 0.18^{b c}$ & $0.27 \pm 0.06^{\mathrm{a}}$ \\
\hline & $-F M$ & $43.50 \pm 2.58 \mathrm{ab}$ & $39.74 \pm 2.40^{\mathrm{ab}}$ & $1.14 \pm 0.09^{c}$ & $0.19 \pm 0.07^{\mathrm{a}}$ \\
\hline \multirow[t]{2}{*}{100} & $+F M$ & $36.10 \pm 3.58^{b c}$ & $32.80 \pm 3.33^{b}$ & $1.38 \pm 0.18^{c}$ & $0.25 \pm 0.14^{\mathrm{a}}$ \\
\hline & $-F M$ & $42.40 \pm 3.58 \mathrm{ab}$ & $39.10 \pm 3.33^{\mathrm{ab}}$ & $1.42 \pm 0.24^{c}$ & $0.17 \pm 0.14^{\mathrm{a}}$ \\
\hline \multirow[t]{2}{*}{150} & $+F M$ & $45.60 \pm 3.41^{a b}$ & $40.50 \pm 4.26^{a b}$ & $2.38 \pm 0.60$ ab & $0.11 \pm 0.02^{\mathrm{a}}$ \\
\hline & - FM & $51.90 \pm 3.41^{\mathrm{a}}$ & $46.82 \pm 4.26^{\mathrm{a}}$ & $0.98 \pm 0.25^{c}$ & $0.02 \pm 0.02^{\mathrm{a}}$ \\
\hline \multirow[t]{2}{*}{ Main effects } & $\mathrm{NaCL}$ & $p<0.001$ & $p<0.001$ & $\mathrm{p}<0.05$ & ns \\
\hline & $\mathrm{AM}$ & $p<0.05$ & $p<0.05$ & $p<0.001$ & ns \\
\hline Interaction effects & $\mathrm{NaCl} \times \mathrm{AM}$ & ns & ns & ns & ns \\
\hline
\end{tabular}


Fig. 3 - Effects of salt stress on total chlorophyll of mycorrhizal and nonmycorrhizal seedlings of Z. spinachristi. Different letters indicate significant differences between treatments $(p<0.05)$

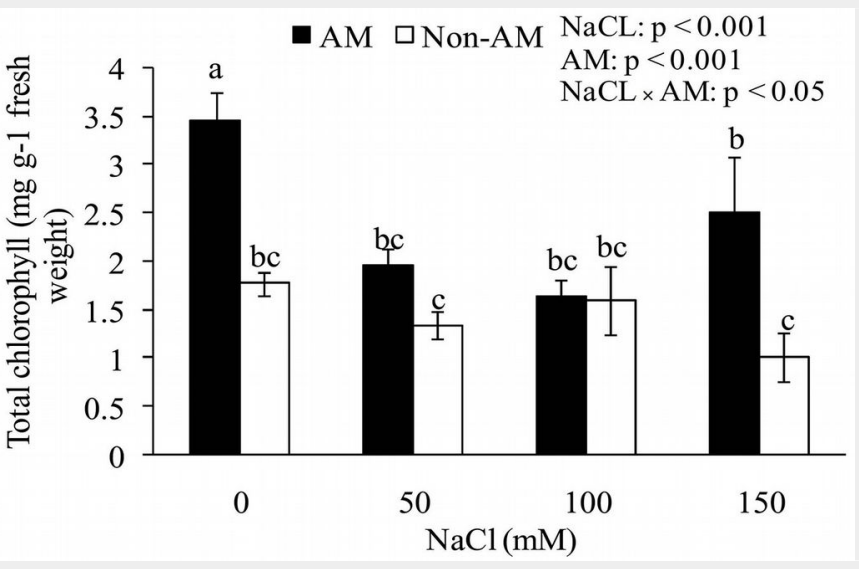

Fig. 4 - Effect of salt stress on proline accumulation in roots of mycorrhizal and non-mycorrhizal seedlings of Z. Spina-christi.

Different letters indicate significant differences between treatments $(\mathrm{p}<0.05)$. (ns): not significant.

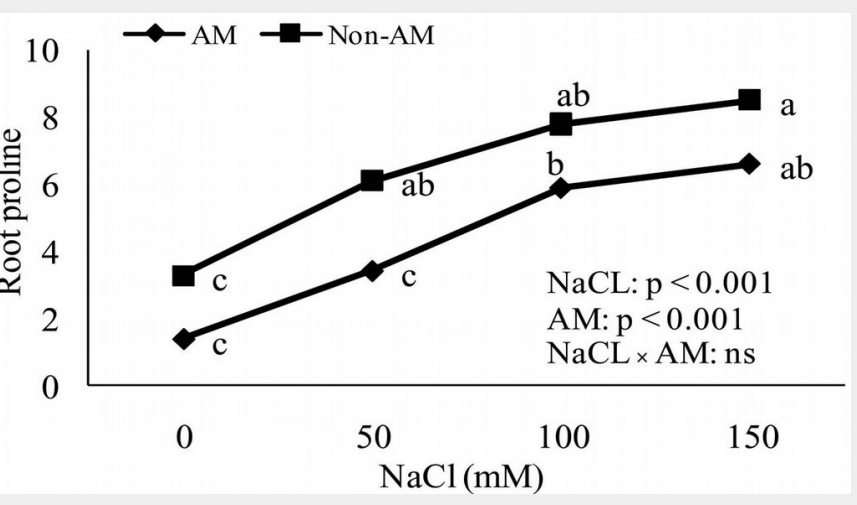

Fig. 5 - Effect of salt stress on proline accumulation in leaves of mycorrhizal and non-mycorrhizal seedlings of Z. spina-christi.

Different letters indicate significant differences between treatments $(\mathrm{p}<0.05)$. (ns): not significant.

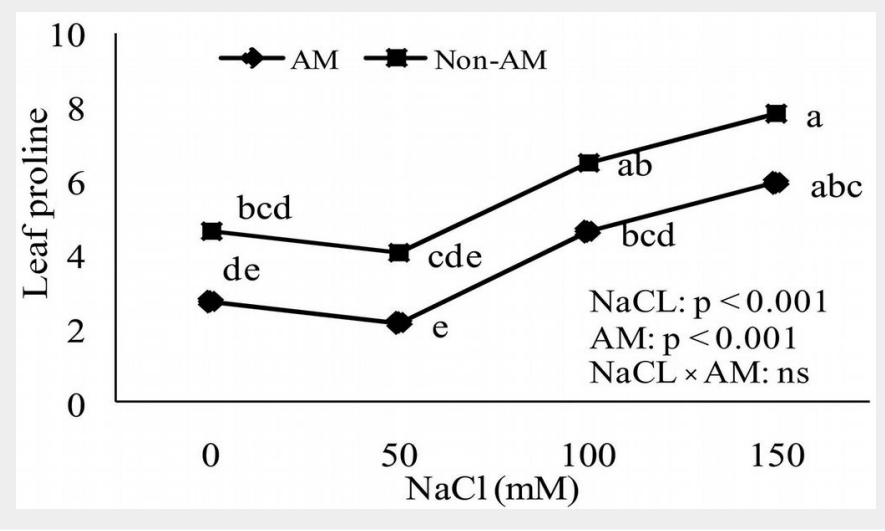

$\mathrm{N}, \mathrm{P}, \mathrm{K}$, and $\mathrm{Na}^{+}$concentrations Leaf $\mathrm{N}$ significantly decreased by increa-

sing $\mathrm{NaCl}$ concentration in the soil for both mycorrhizal and non-mycorrhizal plants.
The FM inoculation increased the $\mathrm{N}$ absorption in leaves of seedlings grown at the lowest salinity by $44.1 \%$, while such increase was $37.5 \%$ for seedlings grown at the highest salinity treatment. Contrastingly, no significant differences were observed in $\mathrm{N}$ absorption in the roots in seedlings grown under any soil salinity and FM treatments (Tab. 3).

In general, a decreased in the $\mathrm{P}$ content of leaves and roots of seedlings grown under salinity stress was observed. However, the $\mathrm{P}$ content in leaves and roots increased respectively by $26.2 \%$ and $24.2 \%$ in FM-inoculated seedlings grown under the lowest salinity treatment, as compared to non-mychorrizal plants, while at the highest salinity treatment such increase was $28.0 \%$ in leaves and $20.8 \%$ in roots.

Concerning $\mathrm{K}$ content, salt stress and $\mathrm{FM}$ inoculation had no significant effects on seedling leaves. On the contrary, soil salinity decreased the $\mathrm{K}$ absorption in the roots. However, as compared with noninoculated plants, mychorrizal seedlings showed an increase of $\mathrm{K}$ in the roots by $36.7 \%$ at the lowest and by $125.0 \%$ at the highest salinity treatments (Tab. 3).

Tab. 4 shows that the $\mathrm{Na}^{+}$content increased in the leaves and roots of both mycorrhizal and non-mycorrhizal plants as the $\mathrm{NaCl}$ concentration in the soil increased. At all levels of soil salinity, the $\mathrm{Na}^{+}$content in the leaves and roots of FM-inoculated seedlings was lower than that observed for non-inoculated seedlings.

\section{Chlorophyll content}

Total chlorophyll and chlorophyll $a$ in mycorrhizal plants were significantly higher than in non-mycorrhizal plants at 0,50, and $150 \mathrm{mM} \mathrm{NaCl}$ (Tab. 4, Fig. 3). In addition, soil salinity levels and the interaction between salinity and the fungus had significant effect on the total chlorophyll content. In other words, by increasing the salinity in the soil the total chlorophyll content of seedling leaves decreased. There were no significant differences between FMinoculated and non-inoculated plants as for chlorophyll $b$. Similarly, the salt stress

Tab. 5 - Effect of salt stress on catalase (CAT), peroxidase (POD) and superoxide dismutase (SOD) of mycorrhizal and non-mycorrhizal seedlings of $Z$. spina-christi. Means \pm standard errors are reported. (+, -): presence/absence of Funneliformis mosseae. Means in the same column followed by the same letter are not significantly different ( $p>0.05)$ after the Duncan's post-hoc test. (ns): not significant.

\begin{tabular}{|c|c|c|c|c|c|c|c|}
\hline \multirow{2}{*}{$\begin{array}{l}\text { Treatment } \\
(\mathrm{mM} \mathrm{NaCl})\end{array}$} & \multirow{2}{*}{$\begin{array}{l}\text { FM } \\
\text { inoculation }\end{array}$} & \multicolumn{2}{|c|}{ CAT (U mg ${ }^{-1}$ protein) } & \multicolumn{2}{|c|}{ POD (U mg-1 protein) } & \multicolumn{2}{|c|}{ SOD (U mg ${ }^{-1}$ protein) } \\
\hline & & Leaf & Root & Leaf & Root & Leaf & Root \\
\hline \multirow[t]{2}{*}{0} & $+\mathrm{FM}$ & $5.31 \pm 1.70^{a}$ & $9.95 \pm 2.73^{c}$ & $6.19 \pm 1.50^{b}$ & $2.75 \pm 1.73^{c}$ & $0.98 \pm 0.23^{d}$ & $1.57 \pm 0.54^{c}$ \\
\hline & - FM & $7.21 \pm 1.70^{a}$ & $11.85 \pm 2.73^{c}$ & $8.09 \pm 1.50^{b}$ & $2.75 \pm 3.60^{c}$ & $2.88 \pm 0.23 \mathrm{bcd}$ & $3.47 \pm 0.54 \mathrm{bc}$ \\
\hline \multirow[t]{2}{*}{50} & $+F M$ & $7.56 \pm 2.90^{a}$ & $14.60 \pm 3.70^{b c}$ & $6.61 \pm 2.10^{b}$ & $6.16 \pm 1.82^{b c}$ & $2.11 \pm 0.41^{\mathrm{cd}}$ & $2.34 \pm 0.73^{b c}$ \\
\hline & $-F M$ & $11.46 \pm 2.40^{\mathrm{a}}$ & $18.90 \pm 3.46^{b c}$ & $8.51 \pm 2.10^{b}$ & $6.16 \pm 3.70^{b c}$ & $4.41 \pm 0.51^{\mathrm{abc}}$ & $4.24 \pm 0.73^{a b}$ \\
\hline \multirow[t]{2}{*}{100} & $+F M$ & $15.36 \pm 7.20^{a}$ & $11.02 \pm 2.25^{c}$ & $15.20 \pm 4.90 a b$ & $2.84 \pm 0.46^{c}$ & $3.28 \pm 1.08^{\mathrm{bcd}}$ & $3.05 \pm 0.66^{b c}$ \\
\hline & - FM & $19.06 \pm 7.70^{a}$ & $14.90 \pm 2.37^{b c}$ & $17.10 \pm 4.90^{a b}$ & $2.84 \pm 0.65^{c}$ & $5.18 \pm 1.08^{a b}$ & $4.95 \pm 0.66^{a b}$ \\
\hline 150 & $-F M$ & $22.47 \pm 8.90^{\mathrm{a}}$ & $40.90 \pm 7.11^{a}$ & $21.80 \pm 5.20^{a}$ & $10.93 \pm 7.70^{a}$ & $6.17 \pm 0.85^{a}$ & $6.78 \pm 1.19^{a}$ \\
\hline \multirow[t]{2}{*}{ Main effects } & $\mathrm{NaCl}$ & ns & $p<0.001$ & $p<0.001$ & $p<0.001$ & $\mathrm{p}<0.001$ & $\mathrm{p}<0.001$ \\
\hline & $\mathrm{AM}$ & ns & ns & ns & ns & $\mathrm{p}<0.001$ & $p<0.001$ \\
\hline Interaction effects & $\mathrm{NaCl} \times \mathrm{AM}$ & ns & ns & ns & ns & ns & ns \\
\hline
\end{tabular}


showed no significant effect on chlorophyll b content (Tab. 4).

\section{Enzyme activity assessment}

The levels of POD, SOD and CAT antioxidant enzymes in inoculated plants exposed to salt stress were lower than for non-inoculated plants. Salinity of the soil was observed to increase the SOD, POD and CAT activity (Tab. 5). In comparison to nonmycorrhizal plants, the activity of SOD enzymes decreased in mycorrhizal plants. In addition, FM inoculation did not significantly affect the activity of CAT and POD enzymes in both roots and leaves of $Z$. spina-christi seedlings.

\section{Proline accumulation}

Accumulation of proline in non-mycorrhizal and mycorrhizal plants increased as soil salinity increased. The proline accumulation in leaves and roots of non-mycorrhizal plants increased significantly compared to mycorrhizal plants at all levels of soil salinity (Fig. 4, Fig. 5).

\section{Discussion}

The results of this study indicate that FM inoculation markedly improved the growth characteristics of $Z$. spina-christi seedlings under salt stress. Tian et al. (2004) demonstrated that inoculation with FM fungi could improve growth of cotton plants under a variety of salt stress conditions. In the present investigation, the tolerance of FM-inoculated plants to salt stress increased compared to non-mychorrizal seedlings, as demonstrated by the increase of fresh weight and other parameters, including the level of colonization, basal diameter and RDW. Indeed, the abundance of fungus hyphae around the host roots may help absorbing poorly mobile nutrients such as $\mathrm{P}$ in the depletion zone of roots. These nutrients are transported into the host plants, resulting in the improvement of seedling growth (Okurowska 2008).

According to Beltrano et al. (2013), we found that the FM colonization of $Z$. spinachristi roots was inversely correlated to $\mathrm{NaCl}$ concentration in the soil (Fig. 1). This decrease in the fungus colonization under salt stress may be due to a reduced germination of fungal spores (Van Aarle et al. 2002, Al-Khaliel 2010).

The beneficial effects of mycorrhiza on growth under saline conditions have been studied in various plant species and families (Al-Khaliel 2010, Evelin \& Kapoor 2013). In the present study, when the plants were exposed to high concentrations of $\mathrm{NaCl}$ in the soil, seedling SDW substantially decreased regardless the presence or absence of mycorrhizal fungi (Fig. 2). The main reasons for the detrimental effects of salinity may be related to the negative osmotic pressure created by salt in the root zone (Jacoby 1994) or to growth inhibition caused by cell injury in transpiring leaves (Tuteja 2007).

In general, FM helped to partially alleviate $\mathrm{NaCl}$ stress; this was evident in the growth of inoculated plants compared to non-inoculated plants. The beneficial effect of FM symbiosis on plant growth has been largely attributed to the higher uptake of phosphorus (Moyersoen et al. 1998). In the present study, plants inoculated with FM showed higher $\mathrm{P}$ contents at all salinity levels, primarily in the roots (Tab. 3). This suggests that the effect of FM on P uptake constitutes a major mechanism for increasing plant tolerance to salinity.

In this study, the $\mathrm{Na}^{+}$concentrations in mycorrhizal seedlings were significantly smaller than in non-mycorrhizal plants. Low $\mathrm{Na}^{+}$concentration in leaves and roots of mycorrhizal plants may be due to positive effect of FM fungus on water absorption. Previous studies have also indicated that FM fungi increase plant growth by reducing $\mathrm{Na}^{+}$uptake (Tian et al. 2004, AlKaraki 2006) and increasing the uptake of other nutrients such as P, K, and N (Al-Karaki 2006, Daei et al. 2009).

The results shown in Fig. 3 indicate that the total chlorophyll and chlorophyll a contents increased in the leaves of FM-inoculated plants as compared with non-mychorrizal plants. However, at $100 \mathrm{mM}$ salinity the chlorophyll contents were at very close range and showed no statistically significant difference $(p>0.05)$. The higher chlorophyll content of FM-inoculated seedlings may reflect the higher photosynthetic rate necessary to support the carbon cost of association with the fungus (Wright et al. 1998). The increased photosynthesis in FM plants may be mediated by the increased $P$ nutrition, as evidenced by increased plant growth. At higher $\mathrm{NaCl}$ concentrations in the soil, the total chlorophyll content decreased (Fig. 3). It has previously been reported that salinity decreased chlorophyll content (Singh et al. 2000); therefore, high levels of $\mathrm{NaCl}$ can decrease the chlorophyll content of leaves.

On the other hand, salt stress also enhanced the SOD and POD activity in roots and leaves and CAT activity just in roots of Z. spina-christi seedlings. It is well known that these enzymes represent an effective mechanism for preventing the negative effects of reactive oxygen species (ROS) under salinity stress (Mirzaei \& Yousefzadeh 2013). In addition, if the stress lasts for a long time, these enzymes will negatively influence the plant (Abdel Latef \& Miransari 2014). FM inoculation acts as a preventive mechanism by decreasing SOD in leaves and roots, thus favoring the avoidance of oxidative damage induced by salt stress (Hildebrandt et al. 2007). Finally, this leads to survive the plant under salt stress (Ouziad et al. 2005).

Proline accumulation is a symptom of stress in less salt-tolerant plants. Proline plays multiple roles in stress tolerance as a mediator of osmotic adjustment (Yoshiba et al. 1997). It also protects macromolecules during dehydration (Sanchez et al. 1998). In the present study, both salt-stressed mycorrhizal and non-mycorrhizal $Z$. spina-christi accumulated free proline (Fig. 4, Fig. 5). The increase in free proline in salt-stressed non-mycorrhizal plants was significantly higher than in inoculated plants at all levels of salinity. This suggests that FM inoculation may favor osmotic adjustments in seedlings by promoting the synthesis of solutes such as proline.

\section{Conclusion}

This study focused on the effects of the mychorrizal fungus Funneliformis mossae (FM) on the growth of Ziziphus spina-christi seedlings under different levels of soil salinity. The results showed that FM inoculation improved the tolerance of plants to salt stress, alleviated the detrimental effects of salinity on growth and improved the nutrition uptake, as evidenced by the higher $\mathrm{K}, \mathrm{P}, \mathrm{N}$ and lower $\mathrm{Na}^{+}$concentrations in leaf tissues. The use of FM-inoculated seedlings is a sustainable and environmentally safe treatment to improve tolerance to salinity in Ziziphus spina-christi seedings. Therefore, root inoculation and colonization by FM can be recommended as an effective strategy to alleviate the deleterious effects of salt stress.

\section{References}

Abdel Latef AA (2013). Growth and some physiological activities of pepper (Capsicum annuum L.) in response to cadmium stress and mycorrhizal symbiosis. Journal of Agricultural Science and Technology 15: 1437-1448. [online] URL: http://jast.modares.ac.ir/article_10220_o.html Abdel Latef AA, Miransari M (2014). The role of arbuscular mycorrhizal fungi in alleviation of salt stress. Use of microbes for the alleviation of soil stresses. Springer Science+Business Media, New York, USA, pp. 23-38. - doi: 10.1007/ 978-1-4939-0721-2_2

Adiku G, Renger $\bar{M}$, Wessolek $G$, Facklam $M$, Hech-Bischoltz C (2001). Simulation of dry matter production and seed yield of common beans under varying soil water and salinity conditions. Agricultural Water Management 47: 5568. - doi: 10.1016/S0378-3774(00)00094-9

Al-Karaki GN (2006). Nursery inoculation of tomato with arbuscular mycorrhizal fungi and subsequent performance under irrigation with saline water. Scientia Horticulture 109: 1-7. - doi: 10.1016/j.scienta.2006.02.019

Al-Khaliel AS (2010). Effect of salinity stress on mycorrhizal association and growth response of peanut infected by Glomus mosseae. Plant, Soil and Environment 56: 318-324. [online] URL: http://81.0.228.28/publicFiles/23415.pdf

Asghari HR, Marschner P, Smith SE, Smith FA (2005). Growth response of Atriplex nummularia to inoculation with arbuscular mycorrhizal fungi at different salinity levels. Plant and Soil 273: 245-256. - doi: 10.1007/s11104-004-7942-6

Bates LS, Waldern RP, Teave ID (1973). Rapid determination of free proline for water stress studies. Plant and Soil 39: 205-207. - doi: 10.1007 /BFo0018060

Beltrano J, Ruscitti M, Arango MC, Ronco M (2013). Effects of arbuscular mycorrhiza inoculation on plant growth, biological and physiological parameters and mineral nutrition in pep- 
per grown under different salinity and P levels. Journal of Soil Science and Plant Nutrition 13 (1): 123-141. [online] URL: http://www.scielo.cl/ scielo.php?pid=S0718-95162013005000012 Bisen PS, Dev A, Gour RK, Jain RK, Sengupta LK (1995). Study of vesicular-arbuscular mycorrhiza fungus Glomus mosseae in soil samples of Bhopal. In: Proceedings of the " 3 rd National Conference of Mycorrhiza”. New Delhi (India), pp. 73-76.

Cakmak I, Horst W (1991). Effect of aluminium on lipid peroxidation, superoxide dismutase, catalase and peroxidase activities in root tip of soybean (Glycine max). Plant Physiology 83: 463468. - doi: 10.1111/j.1399-3054.1991.tboo121.x Daei G, Ardekani MR, Rejali F, Teimuri S, Miransari M (2009). Alleviation of salinity stress on wheat yield, yield components, and nutrient uptake using arbuscular mycorrhizal fungi under field conditions. Journal of Plant Physiology 166: 617-625. - doi: 10.1016/j.jplph.2008.09. 013

Evelin H, Giri B, Kapoor R (2012). Contribution of Glomus intraradices inoculation to nutrient acquisition and mitigation of ionic imbalance in $\mathrm{NaCl}$-stressed Trigonella foenum-graecum. Mycorrhiza 22: 203-217. - doi: 10.1007/s00572-0110392-0

Evelin H, Kapoor R (2013). Arbuscular mycorrhizal symbiosis modulates antioxidant response in salt-stressed Trigonella foenum-graecum plants. Mycorrhiza 24: 197-208. - doi: 10.1007/ s00572-013-0529-4

FAO (2007). FAO land and plant nutrition management service. FAO, Rome, Italy. [online] URL: http://www.fao.org/ag/agl/agll/spush

Gaur A, Adholeya A (2004). Prospects of arbuscular mycorrhizal fungi in phytoremediation of heavy metal contaminated soils. Current Science 86: 528-534. [online] URL: http://www. currentscience.ac.in/Downloads/article_id_086 _04_0528_0534_0.pdf

Giannopolitis CN, Ries SK (1977). Superoxide dismutase I. Occurrence in higher plants. Plant Physiology 59: 309-331. - doi: 10.1104/pp.59.2. 309

Harborne JB (1998). Nitrogen compounds. In: "Phytochemical Methods: A Guide to Modern Techniques of Plant Analysis" (Harborne JB eds). Chapman and Hall, London, UK, pp. 187234. - doi: 10.1007/978-94-009-5570-7_5

Hajiboland R, Aliasgharzadeh N, Laiegh SF, Poschenrieder C (2010). Colonization with arbuscular mycorrhizal fungi improves salinity tolerance of tomato (Solanum lycopersicum L.) plants. Plant and Soil science 331: 313-327. - doi: 10.1007 /s11104-009-0255-z

Hejiden JN, Klironomos M, Ursic P (1998). Mycorrhizal fungal diversity determines plant biodiversity, ecosystem variability and productivity. Nature 396: 69-72. - doi: 10.1038/23932 Hildebrandt U, Regvar M, Bothe H (2007). Arbus- cular mycorrhiza and heavy metal tolerance. Phytochemical 68: 139-146. - doi: 10.1016/j.phyto chem.2006.09.023

Jacoby B (1994). Mechanisms involved in salt tolerance by plants. In: "Handbook of Plant and Crop Stress” (Pessarakli M). Marcel Dekker Inc, New York, USA, pp. 97-123. [online] URL: http:// books.google.com/books?id=xsobnIXZBwQC Jin CW, Sun YL, Cho DH (2012). Changes in photosynthetic rate, water potential, and proline content in kenaf seedlings under salt stress. Canadian Journal of Plant Science 92: 311-319. doi: 10.4141/cjps2011-144

Juniper S, Abbott LK (1993). Vesicular-arbuscular mycorrhizas and soil salinity. Mycorrhiza 4: 4557. - doi: $10.1007 /$ BFo0204058

Kar M, Mishra D (1976). Catalase, peroxidase, and polyphenoloxidase activities during rice leaf senescence. Plant Physiology 57: 315-319. doi: 10.1104/pp.57.2.315

Lu Y, Wang G, Meng Q, Zhang W, Duan B (2014). Growth and physiological responses to arbuscular mycorrhizal fungi and salt stress in dioecious plant Populus tomentosa. Canadian Journal of Forest Research 44: 1020-1031. - doi: 10.1139/cjfr-2014-0009

Meloni DA, Gulotta MR, Martínez CA, Oliva MA (2004). The effects of salt stress on growth, nitrate reduction and proline and glycinebetaine accumulation in Prosopis alba. Brazilian Journal of Plant Physiology 16: 39-46. - doi: 10.1590/S1677-04202004000100006

Mirzaei J, Yousefzadeh H (2013). Peroxidase, superoxide dismutase and catalase activities of the Pistacia khinjuk seedlings under drought stress. Ecopersia 1: 329-337. [online] URL: http://journals.modares.ac.ir/article_11067_1.ht $\mathrm{ml}$

Moyersoen B, Alexander IJ, Fitter AH (1998). Phosphorus nutrition of ectomycorrhizal and arbuscular mycorrhizal tree seedlings from a low land tropical rain forest in Korup National Park, Cameroon. Journal of Tropical Ecology 14: 47-61. - doi: 10.1017/So266467498000054

Nelson DW, Sommers LE (1982). Total carbon, organic carbon and organic matter. In: "Methods of soil analysis" (Page AL, Miller RH, Keeney DR eds). Agronomy Monograph No. 9. American Society of Agronomy, Madison, WI, USA, pp. 539-579.

Okurowska P (2008). Effects of mycorrhizal colonization and fertilization on growth and photosynthesis of sweet basil under salt stress. Journal of Plant Nutrition 31: 497-513. - doi: 10.1080/ 01904160801895027

Ouziad F, Hidebrandt U, Schmelzer E, Bothe H (2005). Differential gene expressions in arbuscular mycorrhizal-colonized tomato grown under heavy metal stress. Journal of Plant Physiology 162: 634-649. - doi: 10.1016/j.jplph.2004.09. 014

Phillips JM, Hayman DS (1970). Improved proce- dures for clearing roots and staining parasitic and vescicular-arbuscular mycorrhizal fungi for rapid assessment of infection. Transactions of British Mycological Society 55: 158-161. - doi: 10.1016/Soo07-1536(70)80110-3

Porras-Soriano A, Soriano-Martín ML, Porras-Piedra A, Azcón R (2009). Arbuscular mycorrhizal fungi increased growth, nutrient uptake and tolerance to salinity in olive trees under nursery conditions. Plant Physiology 166: 1350-1359. doi: 10.1016/j.jplph.2009.02.010

Prasad K, Meghavansi MK, Ali Khan A (2011). Incidence of arbuscular mycorrhizal fungi (AMF) in tree species in arid zones of Ajmer region of Rajasthan. Mycorrhiza News 22 (4): 12-15.

Sanchez FJ, Manzanares M, De Andres EF, Tenorio JL, Ayerbe L (1998). Turgor maintenance, osmotic adjustment and soluble sugar and proline accumulation in 49 pea cultivars in response to water stress. Field Crops Research 59: 225-235. - doi: 10.1016/S0378-4290(98)00125-7 Singh SK, Sharma HC, Goswami AM, Datta SP, Singh SP (2000). In vitro growth and leaf composition of grapevine cultivars as affected by sodium chloride. Biologia Plantarum 43: 283286. - doi: 10.1023/A:1002720714781

Tian CY, Feng G, Li XL, Zhang FS (2004). Different effects of arbuscular mycorrhizal fungal isolates from saline or non-saline soil on salinity tolerance of plants. Applied Soil Ecology 26: 143-148. - doi: 10.1016/j.apsoil.2003.10.010

Tuteja N (2007). Mechanisms of high salinity tolerance in plants. Methods in Enzymology 428: 419-438. - doi: 10.1016/So076-6879(07)28024-3

Van Aarle IM, Olsson PA, Soderstrom B (2002). Arbuscular mycorrhizal fungi respond to the substrate $\mathrm{pH}$ of their extra radical mycelium by altered growth and root colonization. New Physiologist 155: 173-182. - doi: 10.1046/j.14698137.2002.00439.x

Wright DP, Read DJ, Scholes JD (1998). Mycorrhizal sink strength influences whole plant carbon balance of Trifolium repens L. Plant, Cell and Environment 21: 881-891. - doi: 10.1046/j.13 65-3040.1998.00351.x

Wu QS, Zou YN, Liu W, Ye XF, Zai HF, Zhao LJ (2010). Alleviation of salt stress in Citrus seedlings inoculated with mychorriza: changes in leaf antioxidant defense systems. Plant Soil and Environment 56: 470-475. [online] URL: http:// 81.0.228.28/publicFiles/28646.pdf

Yang SJ, Zhang ZL, Xue YX, Zhang ZF, Shi SY (2014). Arbuscular mycorrhizal fungi increase salt tolerance of apple seedlings. Botanical Studies 55: 70-77. - doi: 10.1186/s40529-014-0070-6 Yoshiba Y, Kiyosue T, Nakashima K, YamaguchiShinozaki K (1997). Regulation of levels of proline as an osmolyte in plants under water stress. Plant, Cell and Physiology 38: 1095-1102. doi: 10.1093/oxfordjournals.pcp.a029093 